\title{
Ismertetés: Egy közösségi alapú rendszerdiagram az elhízás okairól
}

\section{A Community Based Systems Diagram of Obesity Causes}

\author{
Ismertetik: Czér Polla $\varangle$, Földesi Judit \\ Országos Közegészségügyi Intézet
}

Szerzők: Steven Allender, Brynle Owen, Jill Kuhlberg, et al.

Megjelenés: PLoS ONE 10(7): e0129683. https://doi.org/10.1371/journal.pone.0129683

Beküldve: 2018. 09. 05.

doi: 10.24365/ef.v59i4.355

Kulcsszavak: közösségi alapú beavatkozás; elhízás megelőzés; oksági diagram

Keywords: community based interventions; obesity prevention; causal loop diagram

\section{A RENDSZERSZEMLÉLET ALKALMAZÁSA A KÖZÖSSÉGI ALAPÚ BEAVATKOZÁSOKBAN}

A rendszerszemlélet alkalmazása a gyermekkori elhízás megelőzésére irányuló intézkedések tervezésében, kivitelezésében és értékelésében a közösségi alapú megelőzés leghatékonyabb módszere. A cikk egy olyan megközelítést mutat be, ami segíthet kialakítani a rendszerorientált közösségi szemléletet az elhízás okainak megértéséhez.

Azáltal, hogy a szakemberek egyre több ismeretre tettek szert az elhízás hátterében lévő okok komplexitását illetően, a rendszerszemlélet a prevenció egyik ígéretes megközelítésévé vált. A rendszerszemlélet alkalmazásának egyik korábbi példája a Foresight projekt volt, ahol a szakértői véleményeket az energia-egyensúlyra ható tényezők összetettségéről oksági diagramok segítségével, vizuálisan jelenítették meg. ${ }^{1} \mathrm{Az}$ ennek eredményeképpen létrejött „elhízás-rendszertérkép” egy olyan oksági modellt kínált, ami az egyéni szintű energiamérlegből indulva épül fel, az összes olyan tényezőt megjelenítve, ami közvetlenül vagy közvetve befolyásolja az energiamérleget. Miután a résztvevők szembesültek a térkép komplexitásával, elkezdték felismerni a megoldásokat az elhízás megelőzésére az egyéni szinttől kezdve egészen a szakpolitika szintjéig, és ez az, amiben a rendszerszemlélet alkalmazásának értéke rejlik.
A rendszerszintű beavatkozások iránti fokozott érdeklődés annak az egyre szélesebb körben elterjedő felismerésnek a következménye, hogy az elhízás prevenciójának az okok komplexitásával kell foglalkoznia több szinten és színtéren egyszerre.

A rendszerszemléletet nagyon régóta alkalmazzák más tudományterületeken, de az elhízás megelőzésével kapcsolatos alkalmazása még nagyon korai szakaszban jár. A rendszerszemléletű megközelítés figyelembe veszi a komplexitást, mivel a befolyásoló tényezők közötti nem lineáris kapcsolatokat, akkumulációkat, visszacsatolási mechanizmusokat, az időbeli késleltetés hatásait, valamint azokat a nem szándékos következményeket is vizsgálja, amik e jellemzők függvényeként jelennek meg, és amiket egy ennél redukcionistább megközelítés nem tudna megfelelően megragadni.

A rendszerszemlélet és az elhízás megelőzésére irányuló erőfeszítések logikus metszetét alkotják a közösségi alapú beavatkozások. Az elhízás megelőzésével kapcsolatban a legújabb Cochraneáttekintés amellett érvel, hogy a prevenció legígéretesebb iránya a komplex, többszintű és többféle stratégián alapuló közösségi alapú beavatkozások alkalmazása. ${ }^{2}$

A rendszertudományi szemléleten belül, a rendszerdinamikai modellezésnél kialakult gyakorlat, hogy az érdekhordozókat bevonják az informális térképek és a formális szimulációs modellek, azaz a 
csoportmodellezés (group model building, GMB) kidolgozásának folyamatába. Bár a csoportmodell építésében résztvevő érdekhordozók többnyire a magánszektorból érkező vezetők vagy kormányzati tisztviselők, már felmerült annak a lehetősége is, hogy különböző közösségi érdekhordozókat is be kellene vonni, hogy ők is teljesebb képet kapjanak, és kezelni tudják az olyan komplex egészségügyi problémákat, mint a gyermekkori elhízás.

A cikk egy olyan kutatás eredményeit mutatja be, amelyet Ausztráliában, egy vidéki város közösségén belül folytattak le annak érdekében, hogy választ kapjanak a gyermekkori elhízás mértékének növekedésére a közösségen belül. A kérdésfeltevés az volt, hogy a csoportmodellezés használata miképpen segíthet egy közösségnek jobban megérteni a gyermekkori elhízás problémáját, és megoldásokat találni rá.

\section{A KUTATÁSRÓL}

Az adatgyűjtés két fázisban történt: konzultáció a fő érdekhordozókkal, majd szélesebb körű konzultáció a közösséggel.

\section{Konzultáció a fö érdekhordozókkal}

Az első fázis célja a különböző ágazatokból érkező érdekhordozók tudásának és tapasztalatainak integrálása volt a gyermekkori elhízás rendszerszintú okairól a közösségen belül. A résztvevők olyan közösségi vezetők voltak, akiknek közvetlen hatása volt a serdülőkor előtt álló gyermekek környezetére. Az adatgyűjtés két 90 perces reggeli találkozó alkalmával valósult meg. A résztvevőket az első alkalommal arra kérték, hogy próbáljanak az elhízásra, mint dinamikus problémára tekinteni, és azonosítsanak minél több olyan tényezőt, ami hatással lehet az elhízásra, vagy amire hatással lehet az elhízás a közösségükön belül. A résztvevőknek mutattak egy diagramot, amely a gyermekkori elhízás előfordulásának időbeli változását szemléltette, és megkérték őket, hogy hozzák létre a saját diagramjukat, amely azokat az egyéb változásokat tartalmazza, amik ugyanabban az időszakban történtek és összefüggésben állhatnak a gyermekkori elhízásban megfigyelt trenddel. A résztvevők azonosították az összefüggéseket, az oksági viszonyokat és a változók közötti kapcsolatok természetét aszerint, hogy a kapcsolat pozitív vagy negatív (egy kapcsolat pozitív volt, ha a változók egy irányba változtak és negatív, ha az ellenkező irányba). Az így létrejött kapcsolódási köröket végül egy oksági diagrammá (causal loop diagram, CLD) állították össze.

A résztvevőket a második alkalommal arra kérték, hogy vizsgálják meg újra, és finomítsanak a már létrejött oksági diagramon, adjanak hozzá minden olyan tényezőt, vagy kapcsolatot, ami kimaradt, és javítsák ki az esetleges hibákat vagy félreértéseket. Az elhízás problémájának vizuális megjelenítése érthető és könnyen követhető módon világított rá az elhízás komplexitására, az összefüggések érthetővé váltak, a résztvevők nagyon gyorsan felismerték a hiányosságokat és a pontatlanságokat, vagyis, elkezdték keresni a megoldásokat.

\section{Konzultáció közösségi szinten}

A második fázisban az oksági diagramot 44 közösségi vezető értékelte és fejlesztette tovább. A résztvevők a közösség olyan tagjai voltak, akik jelentős befolyással voltak azokra a színterekre és környezetre, amelyet gyerekek használnak, ugyanakkor eltérő ágazatokból érkeztek (oktatás, szórakozás, sport, egészségügy), és ennek megfelelően nagyon különböző érdekeket és prioritásokat képviseltek. Az adatgyűjtés egy egész napos közösségi találkozó során valósult meg. A résztvevőknek prezentálták az oksági diagramot és arra kérték őket, jelöljék meg, hogy a diagram mely elemeivel értenek egyet, mely elemeiben bizonytalanok és mi az, amivel nem értenek egyet, továbbá tegyenek javaslatokat arra nézve, hogy miként lehetne a diagramot pontosabbá tenni.

A folyamat végére egy olyan oksági diagram jött létre, ami a közösség saját észrevételeit jelenítette meg arról, hogy ők mit tekintenek a közösségen belül a gyermekkori elhízást meghatározó tényezőknek és okoknak. [1. ábra, 2. ábra, 3. ábra, 4. ábra és 5. ábra] Az oksági diagram előnye volt, hogy lehetővé tette a közösség elképzeléseinek vizuális megjelenítését. A diagram segítségével a résztvevők képessé váltak a rendszerszemlélettel összhangban azonosítani és megmagyarázni az elhízás determinánsait. A modell építésének folyamata pedig a közös munkán keresztül lehetőséget adott a közösséget érintő gyermekkori elhízás komplexitásának mélyebb megértésére is. 
1. ábra: A kutatás eredményeként létrejött diagram a közösségen belül az elhizást befolyásoló tényezőket négy nagy csoportra osztotta: általános fizikai aktivitás, sportolás, gyorsételek és egészségtelen ételek, valamint a társadalmi környezet

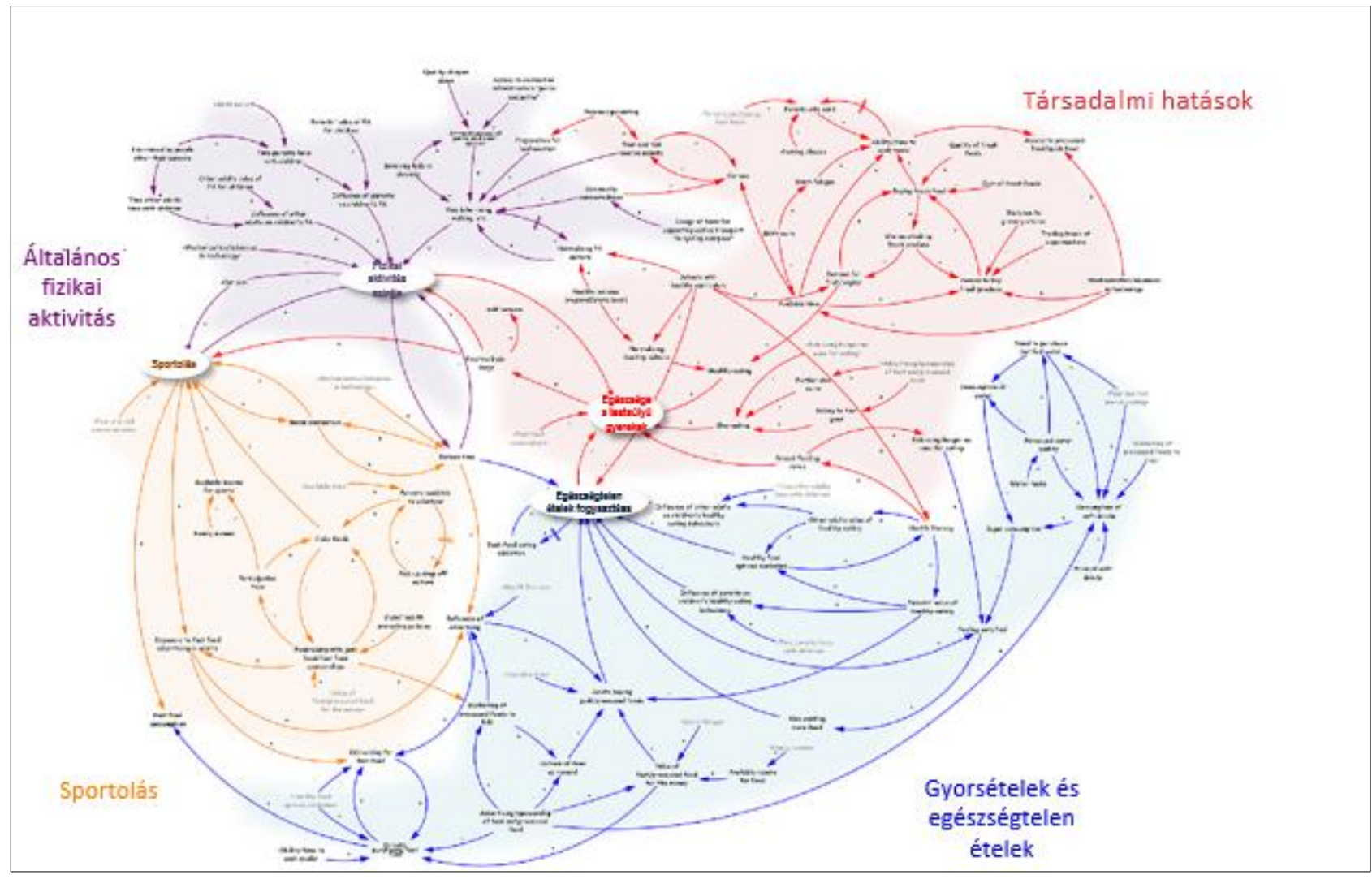

2. ábra: A fizikai aktivitással összefüggésben álló tényezők

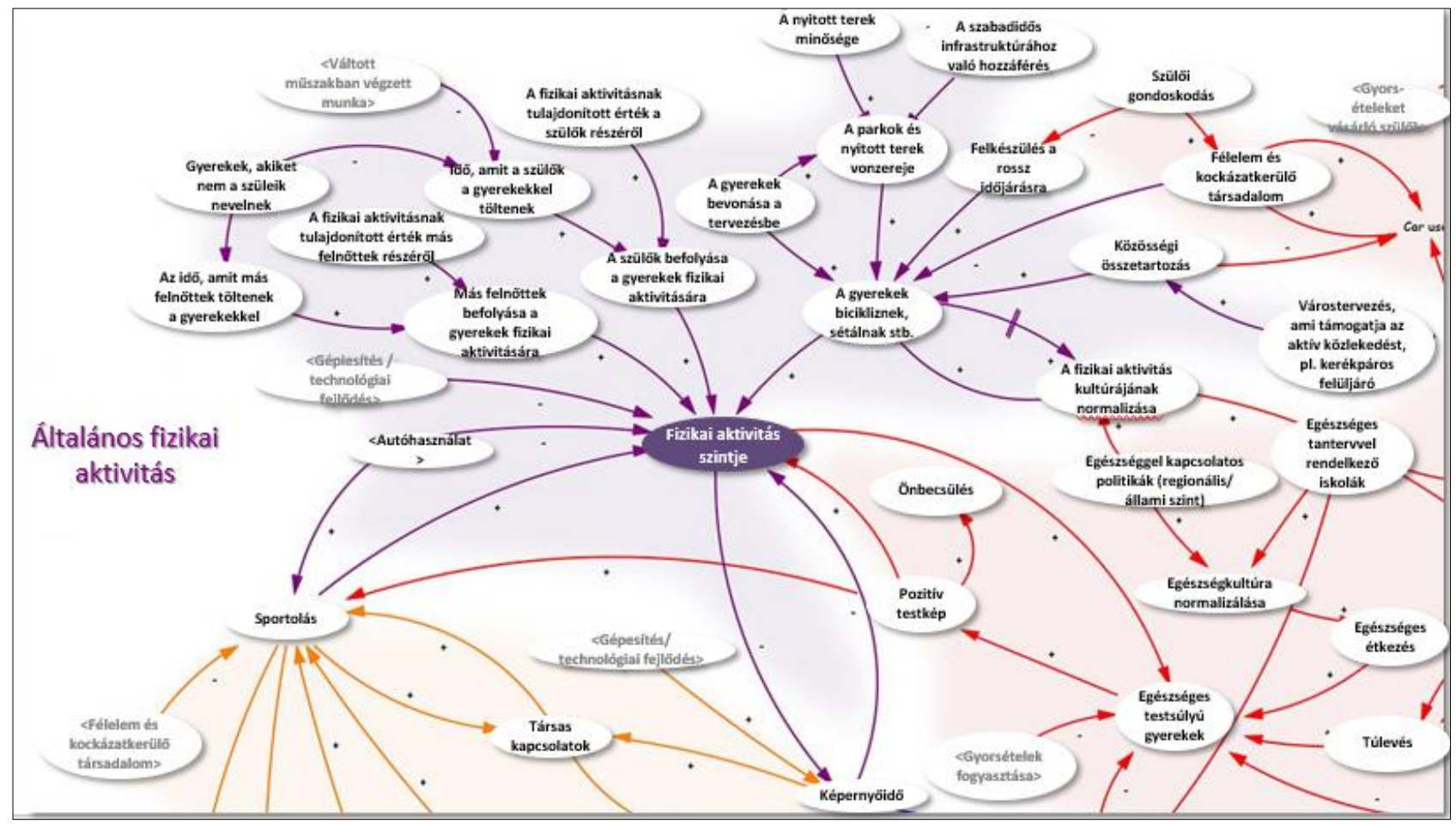


3. ábra: A gyermekkori elhízásra hatással lévő társadalmi tényezők

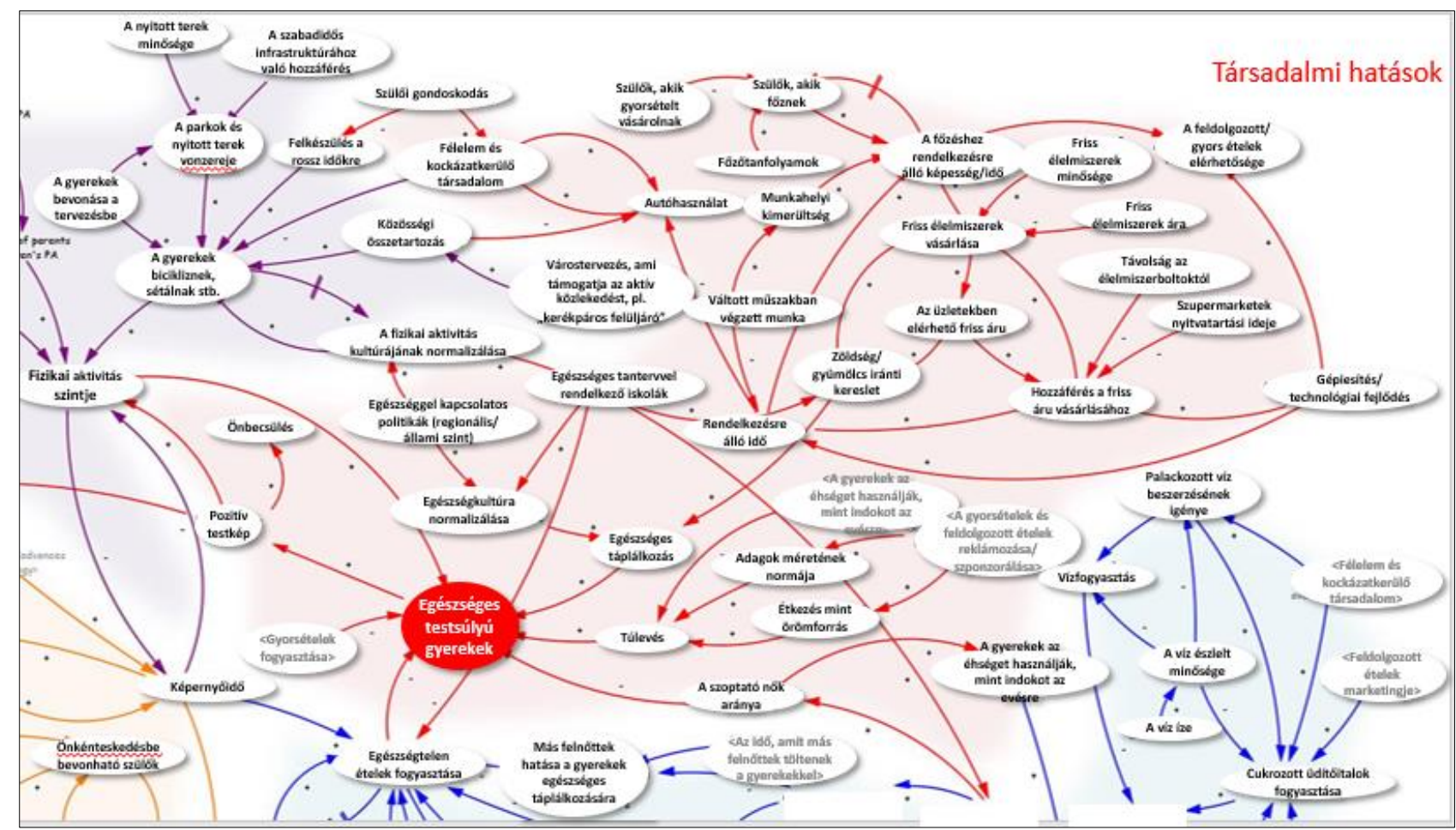

4. ábra: A gyermekkori elhizás és a sportolás

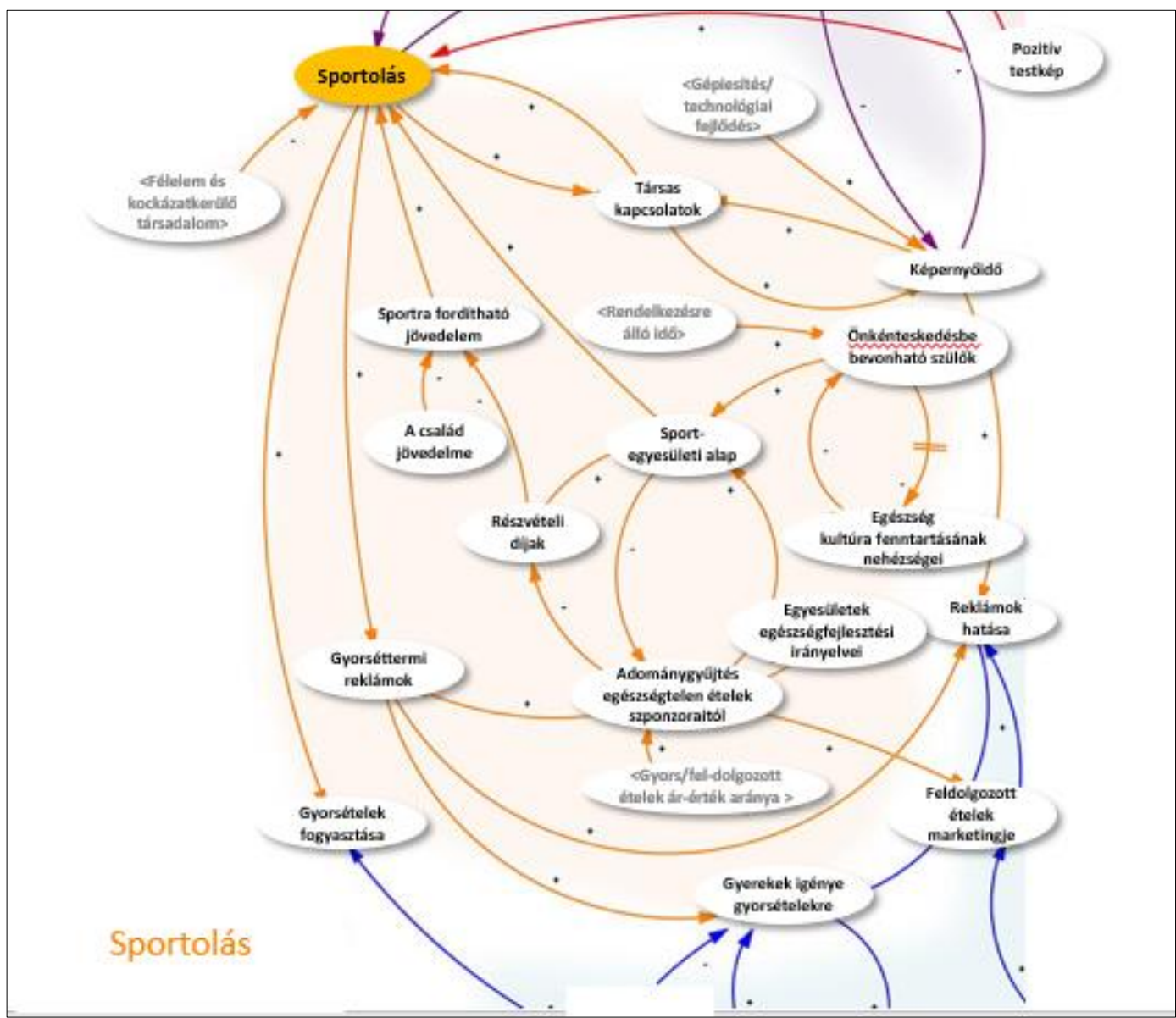




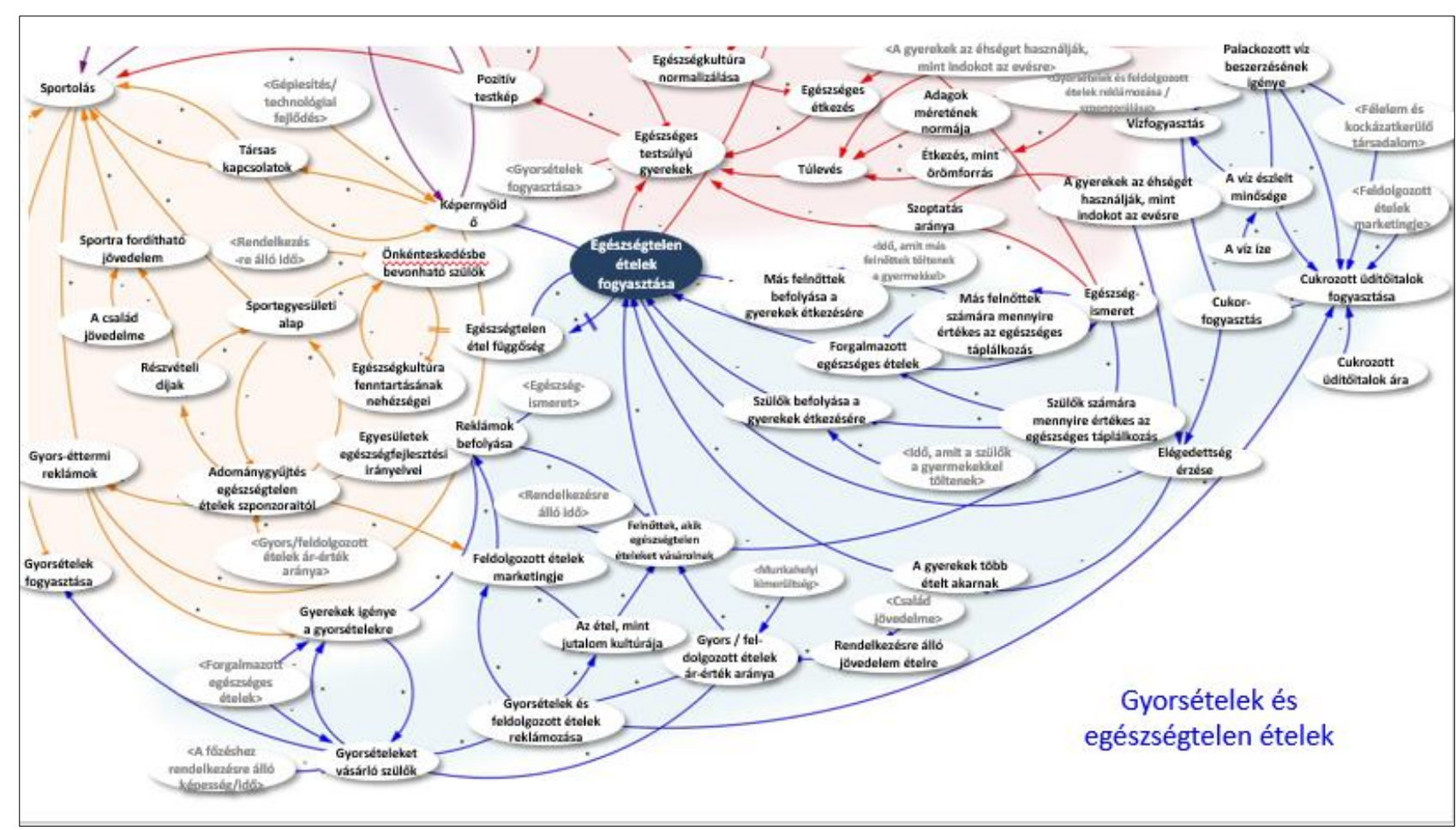

\section{TANULSÁGOK A HAZAI SZAKEMBEREK SZÁMÁRA}

A rendszerszemléletű megközelítés legnagyobb előnye, hogy különböző szintű közösségi szereplőket von be a vezetőktől kezdve mindazokig, akik a szolgáltatások nyújtásában vesznek részt, ezzel növelve a közösség hajlandóságát a változásra, hiszen a politikai akarat, a helyi vezetés és a közösség tagjai is egy oldalon állnak. A kutatás rávilágít arra, hogy a gyermekkori elhízás rendkívül összetett társadalmi jelenség, aminek megelőzése kizárólag az elhízásra ható komplex okok és tényezők figyelembe vételével, és a helyi közösség aktív bevonásával vezethet sikerre.

\section{HIVATKOZÁSOK}

\footnotetext{
${ }^{1}$ Vandenbroeck IP, Goossens J, M.C Foresight Tackling Obesities: Future Choices - Building the Obesity System Map. Government Office for Science, UK Government's Foresight Programme. Available:_https://assets.publishing.service.gov.uk/government/uploads/system/uploads/attachment data/file/295154/07-1179-obesity-building-systemmap.pdf First published in October 2007. (Elérve: 2018.09.09.)

${ }^{2}$ Waters E, de Silva-Sanigorski A, Burford BJ, Brown T, Campbell KJ, Gao Y, et al. (2011) Interventions for preventing obesity in children. Cochrane Database Syst Rev: CD001871.
} 